\title{
RETRACTED ARTICLE: Numerical analysis of multiphase flow in porous material
}

Nadia Laredj • Karim Bendani • Hanifi Missoum •

Mustapha Maliki

Received: 13 May 2011/ Accepted: 22 March 2012/Published online: 16 June 2012

(C) The Author(s) 2012. This article is published with open access at Springerlink.com

This article has been retracted due to plagiarism.

N. Laredj $(\bowtie) \cdot$ K. Bendani · H. Missoum · M. Maliki

Construction, Transport and Protection of the Environment

Laboratory (LCTPE), Université Abdelhamid Ibn Badis de

Mostaganem, 28. A5. Rue Benanteur Charef,

$\mathrm{CP}^{\circ} 27000$ Mostaganem, Algeria

e-mail: nad27000@yahoo.fr 